\title{
Biohydrogen production by locally isolated facultative bacterial species using the biomass of Eichhornia crassipes: effect of acid and alkali treatment
}

 \\ ${ }^{1}$ School of Environmental Sciences, Mahatma Gandhi University, Kottayam, Kerala 686560, India
}

Received: 5 August 2016/Revised: 11 July 2017/Accepted: 13 July 2017/Published online: 24 July 2017

(c) Joint Center on Global Change and Earth System Science of the University of Maryland and Beijing Normal University and Springer-Verlag GmbH Germany 2017

\begin{abstract}
Hydrogen $\left(\mathrm{H}_{2}\right)$ produced from biological methods is a potential option to meet the growing clean energy needs. The present study aimed to produce biohydrogen by dark fermentation from nuisance aquatic weed, Eichhornia crassipes, using facultative anaerobic bacteria. A total of 12 bacterial strains were isolated from different wastewater sources and were screened for the potential of $\mathrm{H}_{2}$ production using glucose as carbon source. Ten strains showed the $\mathrm{H}_{2}$-producing potential and were identified up to the generic level by biochemical tests. Two strains with higher $\mathrm{H}_{2}$ production were sequenced using PCR technique and identified as Proteus mirabilis and Pseudomonas aeruginosa and selected for the studies with $E$. crassipes as the substrate. It was found that $P$. aeruginosa could produce $19.54 \pm 0.03 \%$ of $\mathrm{H}_{2}$ from $2 \%$ acid $\left(\mathrm{H}_{2} \mathrm{SO}_{4}\right)$ treated substrate which was comparatively higher than that of 4 and $8 \%$ treatments. P. mirabilis also yielded better results of $5.42 \pm 0.02 \% \mathrm{H}_{2}$ f or $2 \%$ acid $\left(\mathrm{H}_{2} \mathrm{SO}_{4}\right)$ treated substrate than 4 and $8 \%$ treatments. In total, $33.52 \pm 0.04 \%$ of $\mathrm{H}_{2}$ was produced by $P$. aeruginosa for the substrate treated with $2 \%$ alkali $(\mathrm{NaOH})$. It was noted that with respect to $P$. mirabilis $4 \%$ alkali treated substrate yielded a higher percentage of $\mathrm{H}_{2}(20.23 \pm 0.03 \%)$ compared to the other two concentrations. The results indicate that alkali treated substrate produced comparatively higher amount of $\mathrm{H}_{2}$ than that of acid treated substrates. Regarding efficiency, $P$. aeruginosa was found to be more competent than $P$. mirabilis.
\end{abstract}

V. P. Sylas

mgubioenergy@gmail.com
Keywords Biohydrogen - Dark fermentation . Pseudomonas aeruginosa $\cdot$ Proteus mirabilis $\cdot$ Eichhornia crassipes . Acid and alkali treatment

\section{Introduction}

The extensive use of fossil fuels has depleted the limited resources, and the emissions have been behind the environmental issues like global warming, climate change and ozone depletion (Show et al. 2012; Suleman et al. 2015; Thomas et al. 2016). Hydrogen $\left(\mathrm{H}_{2}\right)$ is considered as a suitable alternative source of energy owing to its regenerative, carbon neutral and high energy yielding $(122 \mathrm{~kJ} / \mathrm{g})$ property (Kapdan and Kargi 2006; Brown et al. 2007; Balat 2008; Das and Veziroglu 2008; Wang and Wan 2009; Suleman et al. 2015). However, presently about $96 \%$ of $\mathrm{H}_{2}$ are produced from fossil fuels, which are again energy intensive, economically and environmentally not feasible (Momirlan and Veziroglu 2002; Nath and Das 2004; Ewan and Allen 2005; Mohanty et al. 2015). Hence, biological methods of $\mathrm{H}_{2}$ production from renewable sources exhibit significant advantages as clean energy and less expensive (Ren et al. 2009; Guo et al. 2010; Pudukudy et al. 2014; Marc and Koohi-Fayegh 2016). The established biological methods are direct biophotolysis by green algae, indirect biophotolysis by cyanobacteria, photofermentation by photosynthetic bacteria and dark fermentation by anaerobic fermentative bacteria (Das and Veziroglu 2008; Oncel and Sukan 2011; Show et al. 2012; Hay et al. 2013).

Dark fermentation involves the conversion of organic substrates to $\mathrm{H}_{2}$ along with butyric, lactic and acetic acid 
by the action of anaerobic fermentative bacteria which has dual advantage of energy production and waste management (Nath and Das 2003; Ren et al. 2009; Hay et al. 2013). Bacteria belonging to varied groups can perform fermentative $\mathrm{H}_{2}$ production (Reginatto and Antônio 2015). Strict anaerobe Clostridium and facultative anaerobes of the family Enterobacteriaceae are the well-established $\mathrm{H}_{2}$ producing strains (Seol et al. 2008; Elsharnouby et al. 2013; Reginatto and Antônio 2015).

Eichhornia crassipes (Mart.) Solms (water hyacinth) is an aquatic weed, having invaded many water bodies, growing vigorously, blanketing the entire water surface and considered as one of the world's 100 worst invaders (Center et al. 1999; Cheng et al. 2010; Luque et al. 2013). Various mechanical, chemical and biological control methods have been implemented for the removal of this noxious weed (Parolin et al. 2012). The control measures adopted worldwide have exhibited varying extent of success, but complete eradication has not yet achieved (Ray et al. 2009; Patel 2012; Stubbs and Kennedy 2012). However, studies have reported that water hyacinth can be a good source of energy owing to the profuse growth and abundance (Mathur and Singh 2004; Gunnarsson and Petersen 2007; Mishima et al. 2008; Chuang et al. 2011; Das et al. 2016). The dry plant biomass mainly comprises of cellulose (18-31\%), hemicellulose (18-43\%) and lignin (7-26\%) $(\mathrm{Ku}-$ mar et al. 2009; Bergier et al. 2012; Barua and Kalamdhad 2016). The high content of carbohydrate can be hydrolysed through acidic and alkaline treatment into fermentable sugars (Kumar et al. 2009; Aswathy et al. 2009; Barua and Kalamdhad 2016). Efforts done to tap the biomass as a suitable feedstock for the production of biofuels like biogas (Vivekanand et al. 2013; Barua and Kalamdhad 2016), bioethanol (Das et al. 2016; Shanab et al. 2017), biohydrogen (Cheng et al. 2010; Chuang et al. 2011; Lazaro et al. 2014) and biodiesel (Shanab et al. 2017) have been proved successful (Kumar et al. 2009; O'Sullivan et al. 2010; Sharma et al. 2016).

Kuttanad, an integral part of Vembanad-Kol Ramsar site, is also adversely affected by various nuisance invasive aquatic macrophytes. E. crassipes is one among the most problematic invasive in the area (Sylas 2010). Hence, the present study has attempted to produce $\mathrm{H}_{2}$ from $E$. crassipes through dark fermentation in the laboratory condition using two locally isolated facultative bacterial species.

\section{Materials and methods}

\subsection{Organism and growth conditions}

The facultative anaerobic bacteria were isolated from different sources of wastewater such as fish market sewage, tapioca processing, coir retting pond and cow dung slurry. These samples were collected in sterilized containers from different locations of Kottayam district, Kerala, India, and brought to the laboratory. The samples $(200 \mathrm{ml})$ were filtered through 2-mm sieve to remove larger particles, then heated in an oven at $100{ }^{\circ} \mathrm{C}$ for about $45 \mathrm{~min}$ and then cooled (Li and Fang 2007). Hundred millilitres of the heattreated wastewater was inoculated into sterile nutrient broth and incubated at $37^{\circ} \mathrm{C}$ in anaerobic condition for 3 days. Subsequently, from this broth, cultures were inoculated onto nutrient agar plates and incubated at $37{ }^{\circ} \mathrm{C}$ for $24 \mathrm{~h}$. Later, the grown colonies were aseptically inoculated into nutrient broth for growth enhancement and used as the inoculums for the further experiments.

\subsection{Screening test for bacteria with hydrogen production potential}

The isolated bacteria were screened for the potential to produce $\mathrm{H}_{2}$. For the screening test, the bacterial cultures were inoculated into nutrient medium containing glucose $(1.5 \%)$ in sterilized distilled water in 250-ml Erlenmeyer flask having screw cap and a port for the gas collection. The final working volume was $200 \mathrm{ml}(150 \mathrm{ml}$ glucose solution, $40 \mathrm{ml}$ nutrient medium and $10 \mathrm{ml}$ bacterial inoculums) (Lay et al. 2013). The nutrient medium consisted of $3.77 \mathrm{~g} / 1$ $\mathrm{NH}_{4} \mathrm{CO}_{3}, 0.125 \mathrm{~g} / \mathrm{l} \mathrm{K}_{2} \mathrm{HPO}_{4}, 2 \mathrm{~g} / \mathrm{l} \quad \mathrm{NaHCO}_{3}, 0.005 \mathrm{~g} / \mathrm{l}$ $\mathrm{CuSO}_{4}, 0.1 \mathrm{~g} / 1 \mathrm{MgCl}_{2}, 0.015 \mathrm{~g} / 1 \mathrm{MnSO}_{4}, 0.025 \mathrm{~g} / 1 \mathrm{FeSO}_{4}$ and $0.00125 \mathrm{~g} / \mathrm{l} \mathrm{CoCl}_{2}$ (Fang and Liu 2002). The initial $\mathrm{pH}$ of the medium was maintained at 7 , and the flasks were purged with $\mathrm{CO}_{2}$ for 5 min and sealed tightly with Teflon tape. It was then kept in anaerobic condition at $37{ }^{\circ} \mathrm{C}$ for 7 days, and all the experiments were done in quadruplicate. After 7 days, the gas from the headspace of the container was collected with a gas-lock syringe and analysed in gas chromatograph.

\subsection{Identification and characterization of bacteria}

The bacterial strains having the potential of $\mathrm{H}_{2}$ production were identified up to the generic level by biochemical characterization and gram staining (Barrow and Feltham 1974). Polymerase chain reaction (PCR) was performed for specieslevel identification of the two bacterial strains which showed higher $\mathrm{H}_{2}$ production. The DNA sequences were searched for similarity using BLAST (basic local alignment search tool) and were submitted in the NCBI GenBank DNA database.

\subsection{Substrate collection and pre-treatment}

The E. crassipes plants were collected from Kuttanad wetland ecosystem, part of Vembanad-Kol Ramsar site, in Kerala, India. The collected plants were first washed with tap water and chopped into small pieces $(2-3 \mathrm{~cm})$ and sun-dried. The dried biomass was then finely powdered in 
Fig. 1 Schematic representation of experimental procedure

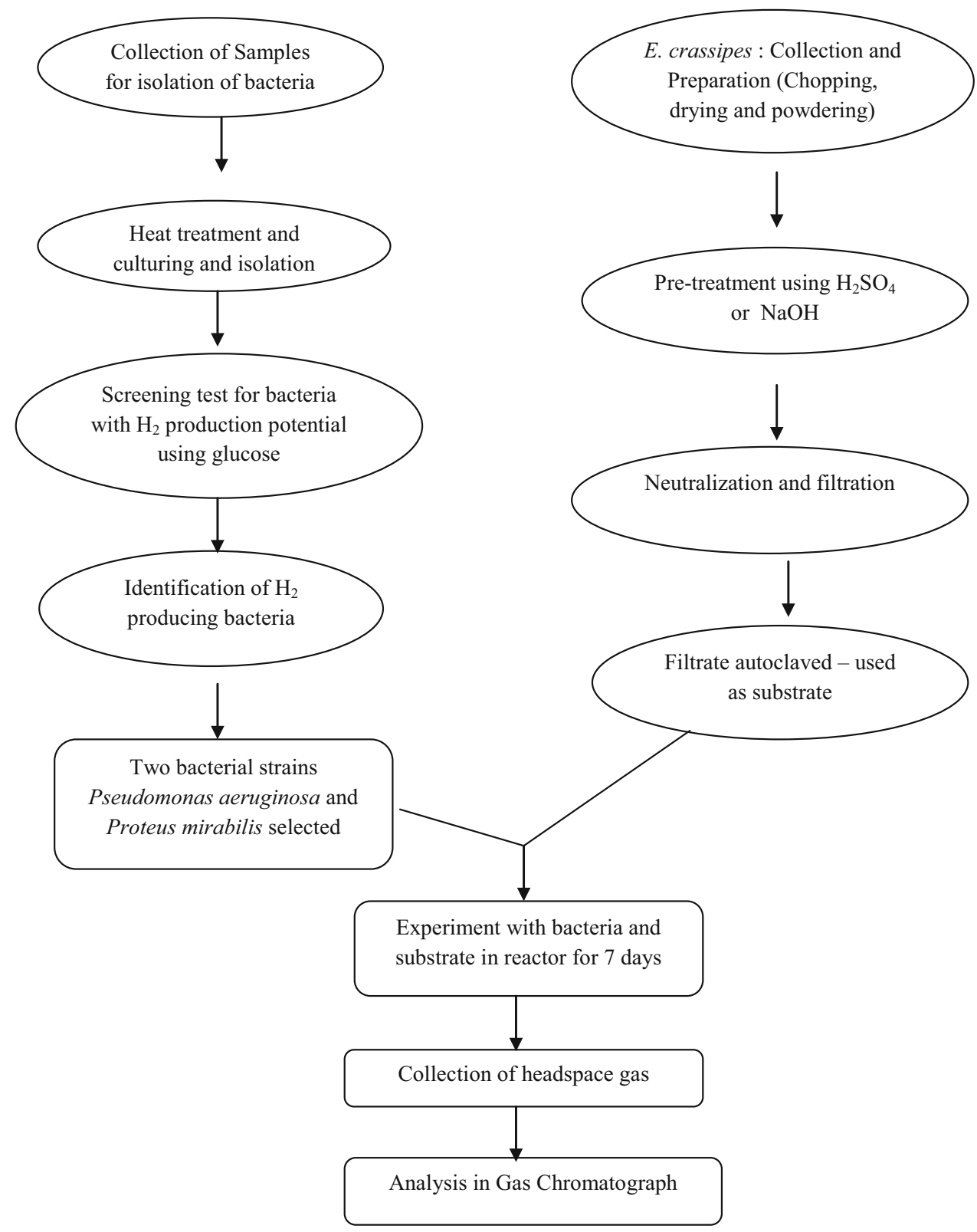

a plant grinder and sieved through 0.25 -micron mesh and stored in airtight containers at room temperature for further analysis. The physico-chemical properties of the biomass were analysed as per APHA (1998) [tests were done with hyacinth solution of $1 \mathrm{~g}$ dried biomass in 11 of deionized water (Lay et al. 2013)]. The biomass was pretreated with different concentrations $(2,4$ and $8 \%)$ of sulphuric acid $\left(\mathrm{H}_{2} \mathrm{SO}_{4}\right)$ as well as sodium hydroxide $(\mathrm{NaOH})$ separately. Ten gram biomass was mixed with either $\mathrm{H}_{2} \mathrm{SO}_{4}$ or $\mathrm{NaOH}$ solution at a solid/liquid ratio of 1:15 and kept under steam treatment at $121{ }^{\circ} \mathrm{C}$ at $15 \mathrm{lbs}$. The pre-treated biomass was then neutralized with acid or alkali and then filtered using Whatman filter paper no: 1 . The filtrate was finally sterilized and used as substrate for the experiments.

\subsection{Experimental set-up} selected for the tests with substrate. The experiments were performed in the similar manner as the screening test with glucose mentioned above in Sect. 2.2. The gas produced was analysed in gas chromatograph. The schematic representation of the entire work is shown in Fig. 1.

\subsection{Analytical methods}

The $\mathrm{pH}$ of the experiments was measured using a portable $\mathrm{pH}$ metre. Glucose content was determined using phenol sulphuric acid method (DuBois et al. 1956), and COD was estimated using open reflux method (APHA
The two bacteria with higher $\mathrm{H}_{2}$ production potential were 
Table 1 Hydrogen production from the isolated bacteria

\begin{tabular}{llll}
\hline S1. no & Strain code & Identified bacterial genera & $\mathrm{H}_{2}(\mathrm{ml})$ \\
\hline 1 & HPB1 & Proteus & 5.15 \\
2 & HPB2 & Salmonella & 0.83 \\
3 & HPB3 & Providencia & 0.045 \\
4 & HPB4 & Klebsiella & 0.045 \\
5 & HPB5 & Providencia & 0.415 \\
6 & HPB6 & Klebsiella & 0.155 \\
7 & HPB7 & Klebsiella & 0.7 \\
8 & HPB8 & Salmonella & 0.305 \\
9 & HPB9 & Salmonella & 0.0 \\
10 & HPB10 & Pseudomonas & 9.94 \\
11 & HPB11 & Salmonella & 0.065 \\
12 & HPB12 & Providencia & 0.0 \\
\hline
\end{tabular}

1998). The headspace gas was analysed in gas chromatograph (Nucon, India, Model 5700) equipped with thermal conductivity detector (TCD). Isothermal separation was done in a packed 2-m-long Porapak Q (80/100) mesh column. The operating temperature of injection port, the oven and the detector was set at 80,60 and $100{ }^{\circ} \mathrm{C}$, respectively. Nitrogen was used as the carrier gas at a flow rate of $20 \mathrm{ml} / \mathrm{min}$.

\section{Results and discussion}

\subsection{Bacteria: isolation, screening of $\mathrm{H}_{2}$ production potential and identification}

A total of 12 bacterial strains were obtained through the heat treatment and subsequent culturing and were named as HPB 1-12. Among them, ten strains showed $\mathrm{H}_{2}$ production in the screening test (Table 1). Two strains, HPB1 and
HPB10, were found to produce higher percentage of hydrogen, and hence, they were selected for the further study of anaerobic fermentation with $E$. crassipes.

The identified bacterial strains belonged to five different genera, namely Salmonella, Pseudomonas, Proteus, Klebsiella and Providencia. The $\mathrm{H}_{2}$-producing capability of Salmonella (Watanapokasin et al. 2009), Pseudomonas (Xie et al. 2008; Soniagandhi and Krishnaveni 2013), Proteus (Patel et al. 2010), Klebsiella (Costa et al. 2011) and Providencia has already been reported.

The DNA sequence data revealed the strains as HPB1 showing 100\% similarity with Proteus mirabilis (Fig. 2) and HPB10 showing 100\% similarity with Pseudomonas aeruginosa (Fig. 3). The accession numbers for the submitted sequence data in NCBI GenBank are Proteus mirabilis KY817361 and Pseudomonas aeruginosa KY817362.

\subsection{Hydrogen production: effect of acid pre- treatment}

The dried E. crassipes is composed of cellulose (22.3\%), hemicellulose (39.8\%) and lignin (20.6\%). These complex organic compounds could not be degraded directly by the bacteria (Su et al. 2010). Direct conversion of raw substrate to $\mathrm{H}_{2}$ is difficult due to complex nature of lignin hemicellulose-cellulose complex; hence, various pre-treatment methods were carried out to break down the complex structure into simpler fragments so as to enable the bacterial action (Singhal and Singh 2014). Acidic and alkaline pre-treatment helps in the breakdown of cellulose into simpler monomer units of glucose (Sun and Cheng 2002; Li and Fang 2007; Aswathy et al. 2009). Glucose is the carbon source on which microbial communities act upon to produce hydrogen through fermentation (Benemann 1996; Das and Veziroglu 2001; Levin et al. 2006; Guo et al. 2010). In the present study, both acid and alkali treatments (concentrations of 2, 4 and 8\%) were employed for the

\begin{tabular}{l}
\hline TGCAGTCGAGCGGTAACAGGAGAAAGCTTGCTTTCTTGCTGACGAGCGGCGGACGGTGAGTAATGTATGGGGATC \\
TGCCCGATAGAGGGGGATAACTACTGGAAACGGTGGCTAATACCGCATAATGTCTACGGACCAAAGCAGGGGCTC \\
TTCGGACCTTGCACTATCGGATGAACCCATATGGGATTAGCTAGTAGGTGGGGTAAAGGCTCACCTAGGCGACGAT \\
CTCTAGCTGGTCTGAGAGGATGATCAGCCACACTGGGACTGAGACACGGCCCAGACTCCTACGGGAGGCAGCAGT \\
GGGGAATATTGCACAATGGGCGCAAGCCTGATGCAGCCATGCCGCGTGTATGAAGAAGGCCTTAGGGTTGTAAAG \\
TACTTTCAGCGGGGAGGAAGGTGATAAGGTTAATACCCTTATCAATTGACGTTACCCGCAGAAGAAGCACCGGCT \\
AACTCCGTGCCAGCAGCCGCGGTAATACGGAGGGTGCAAGCGTTAATCGGAATTACTGGGCGTAAAGCGCACGCA \\
GGCGGT
\end{tabular}

Fig. 2 Consensus sequence data of HPB1-Proteus mirabilis 


TCGAGCGGATGAAGGGAGCTTGCTCCTGGATTCAGCGGCGGACGGGTGAGTAATGCCTAGGAATCTGCCTGGTAG
TGGGGGATAACGTCCGGAAACGGGCGCTAATACCGCATACGTCCTGAGGGAGAAAGTGGGGGATCTTCGGACCTC
GTCTGAGAGGATGATCAGTCACACTGGAACTGAGACACGGTCCAGACTCCTACGGGAGGCAGCAGTGGGGAATAT
TGGACAATGGGCGAAAGCCTGATCCAGCCATGCCGCGTGTGTGAAGAAGGTCTTCGGATTGTAAAGCACTTTAAG
TTGGGAGGAAGGGCAGTAAGTTAATACCTTGCTGTTTTGACGTTACCAACAGAATAAGCACCGGCTAACTTCGTGC
CAGCAGCCGCGGTAATACGAAGGGTGCAAGCGTTAATCGGAATTACTGGGCGTAAAGCGCGCGTAGGTGGTTCAG
CAAGTTGGATGTGAAATCCCCGGGCTCAACCTGGGAACTGCATCCAAAACTACTGAGCTAGAGTACGGTAGAGGG
TGGTGGAATTTCCTGTGTAGCGGTGAAATGCGTAGATATAGGAAGGAACACCGTGGCGAAGGCGACCACCTGGAC
TGATACTGACACTGAGGTGCGAAAGCGTGGGGAGCAAACAGGATTAGATACCCTGGTAGTCCACGCCGTAAACGA
TGTCGACTAGCCGTTGGGATCCTTGAGATCTTAGTGGCGCAGCTAACGCGATAAGTCGACCGCCTGGGGAGTACGG
CCGCAAGGTTAAAACTCAAATGAATTGACGGGGGCCCGCACAAGCGGTGGAGCATGTGGTTTAATTCGAAGCAAC
GCGAAGAACCTTACCTGGCCTTGACATGCTGAGAACTTTCCAGAGATGGATTGGTGCCTTCGGGAACTCAGACACA
GGTGCTGCATGGCTGTCGTCA

Fig. 3 Consensus sequence data of HPB10-Pseudomonas aeruginosa

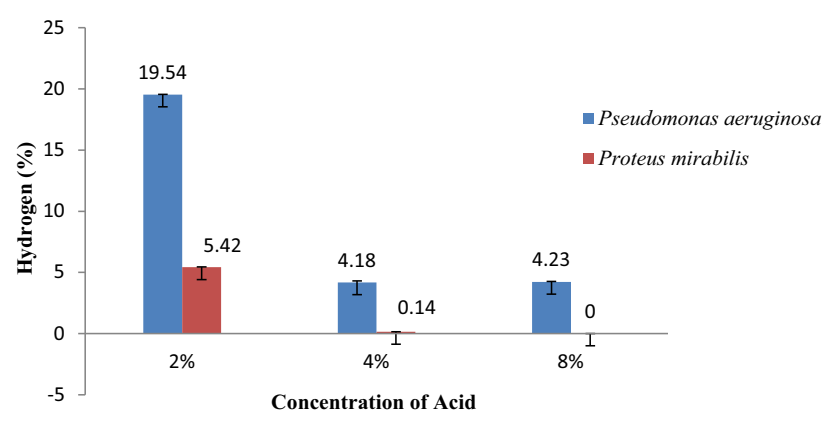

Fig. $4 \mathrm{H}_{2}$ production (\%) with acid treatment substrates using the two bacteria

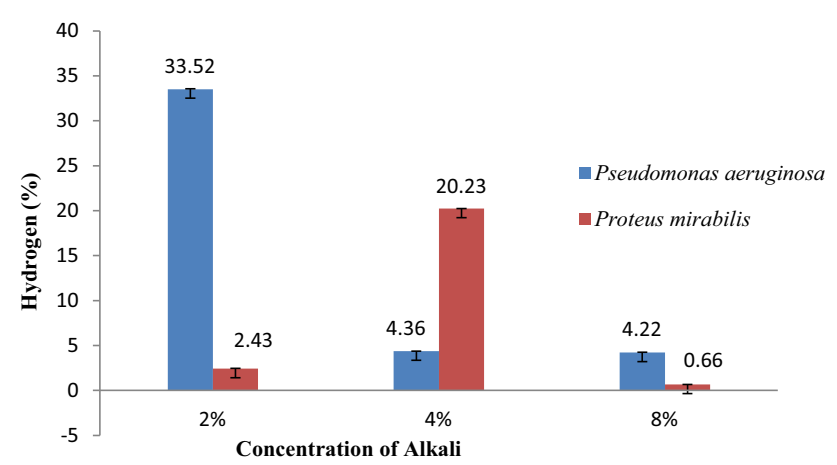

Fig. $5 \mathrm{H}_{2}$ production (\%) with alkali treatment substrates using the two bacteria

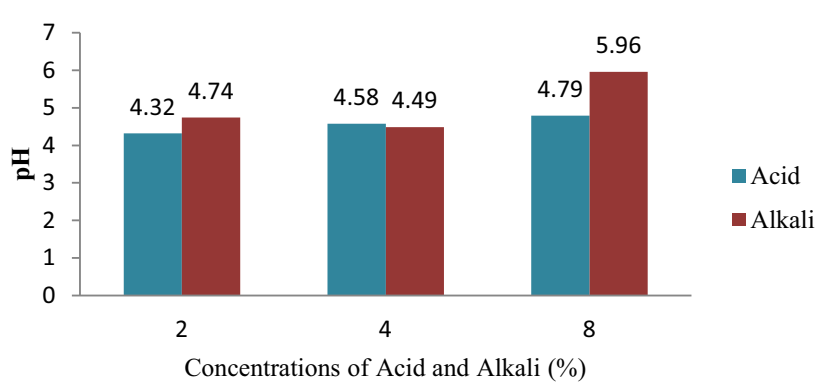

Fig. 6 Final $\mathrm{pH}$ of the solution with $P$. aeruginosa



Fig. 7 Final $\mathrm{pH}$ of the solution with $P$. mirabilis

conversion of polysaccharides into simple sugars. Later, the isolated bacterial species, $P$. aeruginosa and P. mirabilis, were inoculated for the production of $\mathrm{H}_{2}$ under anaerobic condition.

In acidic pre-treatment, the acid hydrolyses hemicelluloses into xylose (Cui et al. 2009; Thomsen et al. 2006). 
Table 2 Percentage degradation of sugar

\begin{tabular}{llll}
\hline \multicolumn{2}{l}{ Concentration (\%) } & \multicolumn{2}{l}{$\%$ degradation of sugar } \\
\cline { 3 - 4 } & & P. aeruginosa & P. mirabilis \\
\hline \multirow{2}{*}{ Acid } & 2 & 81.34 & 47.67 \\
& 4 & 48.79 & 21.13 \\
\multirow{3}{*}{ Alkali } & 8 & 49.73 & 20.93 \\
& 2 & 87.56 & 33.82 \\
& 4 & 47.42 & 82.13 \\
& 8 & 48.93 & 24.79 \\
\hline
\end{tabular}

Table 3 Percentage COD reduction

\begin{tabular}{llll}
\hline \multicolumn{2}{l}{ Concentration (\%) } & \multicolumn{2}{l}{ \% COD reduction } \\
\cline { 3 - 4 } & & P. aeruginosa & P. mirabilis \\
\hline \multirow{2}{*}{ Acid } & 2 & 67.90 & 56.93 \\
& 4 & 63.45 & 50.21 \\
\multirow{3}{*}{ Alkali } & 8 & 59.76 & 39.98 \\
& 2 & 71.34 & 47.23 \\
& 4 & 44.89 & 69.87 \\
& 8 & 56.76 & 37.54 \\
\hline
\end{tabular}

The bacteria, $P$. aeruginosa and $P$. mirabilis, could produce $\mathrm{H}_{2}$ using the pre-treated substrate (E. crassipes) under anaerobic fermentation. In the present study, the percentage of $\mathrm{H}_{2}$ production with $P$. aeruginosa was found to be higher for the substrate treated with $2 \%$ acid $(19.54 \pm 0.03 \%)$ than that of 4 and $8 \%$ acid treated substrates $\left(4.18 \pm 0.13\right.$ and $4.23 \pm 0.04 \% \mathrm{H}_{2}$, respectively) (Fig. 3). Likewise, for P. mirabilis also similar trend was observed, i.e. $2 \%$ acid treated substrate yielded better result $(5.42 \pm 0.02 \%)$ than 4 and $8 \%$ treated substrates ( $0.14 \pm 0.02$ and $0 \% \mathrm{H}_{2}$, respectively) (Fig. 4). In terms of $\mathrm{H}_{2}$ yield, it was $9.77 \pm 0.01, \quad 2.09 \pm 0.06$ and $2.12 \pm 0.02 \mathrm{ml} \mathrm{H}_{2} / \mathrm{g}$ substrate, respectively, for 2,4 and $8 \%$ acid treated substrates for $P$. aeruginosa. And for $P$. mirabilis, the yield was $2.71 \pm 0.01,0.07 \pm 0.01$ and $0 \mathrm{ml}$ $\mathrm{H}_{2} / \mathrm{g}$ substrate, respectively, for 2,4 and $8 \%$ acid treated substrates.

The result showed that low acid concentration gave better yield. Similarly, the mild acid treatment of water hyacinth yields high ethanol production (Ma et al. 2010; Sathyanagalakshmi et al. 2011; Idrees et al. 2013). The increased acid concentration lowered the $\mathrm{H}_{2}$ production due to the conversion of the available sugars to other compounds like xylose, acetic acid and furfural (Aguilar et al. 2002). Furfural and soluble lignin compounds generated during the acid hydrolysis are inhibitors of the fermentation and can even stop the fermentation (Ramos 2003).

\subsection{Effect of alkali pre-treatment}

Alkaline pre-treatment results in an increase in the internal surface by cellulose swelling, decrease in polymerization degree and structural alteration of lignin. The treatment also causes the crystallinity destruction of links between lignin and other polymers, causing the breakdown of lignin (Sun and Cheng 2002; Ibrahim et al. 2011; Yan et al. 2015). Alkaline pre-treatment changes the structures and properties of cellulosic fibres and improves the enzymatic digestibility of fibres (Zhu et al. 2004; Teater et al. 2011). The percentage of $\mathrm{H}_{2}$ production for the substrate treated with $2 \%$ alkali with $P$. aeruginosa was $33.52 \pm 0.04 \%$, which is higher than that of 4 and $8 \%$ alkali treated substrates $\left(4.36 \pm 0.02\right.$ and $4.22 \pm 0.03 \% \mathrm{H}_{2}$, respectively) (Fig. 5). The $4 \%$ alkali substrate yielded a higher percentage of $\mathrm{H}_{2}$ compared to other two concentrations for $P$. mirabilis. The percentage of $\mathrm{H}_{2}$ was $2.43 \pm 0.02 \%$ for $2 \%$ alkali treated substrate and $20.23 \pm 0.03 \%$ for $4 \%$ treated substrate and $0.66 \pm 0.02 \%$ for $8 \%$ alkali treated substrate (Fig. 5). In terms of yield, it was $16.76 \pm 0.02$, $2.18 \pm 0.01$ and $2.11 \pm 0.01 \mathrm{ml} \mathrm{H}_{2} / \mathrm{g}$ substrate, respectively, for 2,4 and $8 \%$ alkali treated substrates for $P$. aeruginosa. And for $P$. mirabilis, the yield was $1.21 \pm 0.01,10.11 \pm 0.01$ and $0.33 \pm 0.01 \mathrm{ml} \mathrm{H}_{2} / \mathrm{g}$ substrate, respectively, for 2,4 and $8 \%$ alkali treated substrates.

A similar trend was obtained in other studies also; higher $\mathrm{H}_{2}$ yields were obtained with alkaline pre-treated sludge (Cai et al. 2004). Alkaline pre-treatment enhances the enzymatic hydrolysis, thereby facilitating $\mathrm{H}_{2}$ production (Su et al. 2010; Aswathy et al. 2009). During alkaline treatment, the $\mathrm{H}_{2}$ produced was maintained and less consumed within the reactor; thus, the higher amount is present at the end of the experiments (Cai et al. 2004). Alkaline pre-treatment causes less sugar transformation (Antonopoulou and Lyberatos 2011; Ibrahim et al. 2011; Sills and Gossett 2011) making the sugars available for microbial action.

Presence of methane was not observed in any of the reactors. This might be the positive effect of heat pretreatment of raw inoculums. The heat pre-treatment was done to eliminate $\mathrm{H}_{2}$-consuming methanogens and selectively favour the growth of $\mathrm{H}_{2}$ producers (Lin et al. 2006; Li and Fang 2007; Sivaramakrishna et al. 2014).

\subsection{Process variables: $\mathrm{pH}, \mathrm{COD}$ and glucose}

At the end of the experiments, the $\mathrm{pH}$ dropped to acidic range in all the reactors for both the treatments (Figs. 6 and 7). This decrease is owed to the production of acidic intermediates such as volatile fatty acids (Alkaya and Demirer 2011), which was not quantified in the present 
Table 4 Biohydrogen production from different substrates by dark fermentation

\begin{tabular}{|c|c|c|c|}
\hline Substrate & Microorganism used & $\mathrm{H}_{2}$ yield & References \\
\hline Glucose & Klebsiella oxytoca $\mathrm{HP} 1$ & $1.0 \mathrm{~mol} \mathrm{H}_{2} / \mathrm{mol} \mathrm{substrate}$ & Minnan et al. (2005) \\
\hline Jackfruit peel & Cow dung slurry & $55 \pm 2 \% \mathrm{H}_{2}$ & Vijayaraghavan et al. (2006) \\
\hline Molasses & Mixed microbial culture & $3.47 \mathrm{~mol} / \mathrm{mol}$ substrate & Guo et al. (2008) \\
\hline Wheat powder & E. aerogenes & $545 \mathrm{ml} \mathrm{H}_{2} / \mathrm{g}$ starch & Argun et al. (2009) \\
\hline Water hyacinth & Anaerobic sludge & $51.7 \mathrm{ml}-\mathrm{H}_{2} / \mathrm{g}-\mathrm{TVS}$ & Cheng et al. (2010) \\
\hline Sugarcane bagasse & Elephant dung & $0.84 \mathrm{~mol} \mathrm{H}_{2} / \mathrm{mol}$ total sugar & Fangkum and Reungsang (2011) \\
\hline Cheese whey powder & Anaerobic seed sludge & $1.03 \mathrm{~mol} / \mathrm{mol}$ substrate & Kargi et al. (2012) \\
\hline Pineapple waste & Anaerobic seed sludge & $1.83 \mathrm{~mol} \mathrm{H}_{2} / \mathrm{mol}$ glucose & Reungsang and Sreela-or (2013) \\
\hline Rice straw & Clostridium pasteurianum & $0.44 \mathrm{~mol} \mathrm{H}_{2} / \mathrm{mol} \mathrm{T}$-sugar & Liu et al. (2013) \\
\hline Water hyacinth & Pig slurry & $13.65 \mathrm{ml} / \mathrm{g}$ feedstock & Lay et al. (2013) \\
\hline Benincasa hispida & Mixed microbial culture & $14 \mathrm{mmol} \mathrm{H}_{2} / \mathrm{mol}$ sugar & Singhal and Singh (2014) \\
\hline Vegetable waste & Seed microflora & $2.2 \mathrm{~mol} / \mathrm{mol}$ substrate & Marone et al. (2014) \\
\hline Sugar beet juice & Anaerobic digested sludge & $3.2 \mathrm{~mol} \mathrm{H}_{2} / \mathrm{mol}$ hexose & Dhar et al. (2015) \\
\hline Waste peach pulp & Anaerobic sludge & $123 \mathrm{ml} \mathrm{H}_{2} / \mathrm{g}$ TOC & Argun and Dao (2016) \\
\hline Raw cassava starch & Mixed microbial culture & $1.72 \mathrm{~mol} \mathrm{H}_{2} / \mathrm{mol}$ glucose & Wang et al. (2017) \\
\hline Water hyacinth & P. aeruginosa & $16.76 \mathrm{ml} \mathrm{H}_{2} / \mathrm{g}$ substrate & Present study \\
\hline Water hyacinth & P. mirabilis & $10.11 \mathrm{ml} \mathrm{H}_{2} / \mathrm{g}$ substrate & Present study \\
\hline
\end{tabular}

study. Volatile fatty acid productions are interrelated with $\mathrm{H}_{2}$ production (Prakasaham et al. 2009).

The substrate had an initial sugar content of $2.2 \mathrm{mg} / \mathrm{g}$. The sugar degradation values ranged from 48.79 to $81.34 \%$ in acid treated substrates and $47.42-87.56 \%$ in alkali treated substrates for the bacteria $P$. aeruginosa (Table 2). For the bacteria $P$. mirabilis, in acid treated substrates, the values ranged from 20.93 to $47.67 \%$ and in alkali treated substrates the values ranged from 24.79 to $82.13 \%$. The sugar degradation values are in accordance with the result of hydrogen production, and the higher degradation percentage was shown in the reactor which produced higher percentage of $\mathrm{H}_{2}$. Pure glucose substrates show $100 \%$ sugar degradation efficiency (Kumar et al. 2013; Nasra et al. 2014), and the less degradation exhibited in the study may be due to the composite nature of the substrate (Kumar et al. 2013).

The initial chemical oxygen demand (COD) of the substrate was $390 \mathrm{mgO}_{2} / 1$. The COD reduction percentage ranged between 59.76 and $67.90 \%$ for $P$. aeruginosa in acid treated substrate and 44.89 and $71.34 \%$ in alkali treated substrates (Table 3). The values ranged from 39.98 to $56.93 \%$ in acid treated substrate for P. mirabilis, and in alkali treated substrates it ranged from 37.54 to $69.87 \%$ (Table 3). From the overall results, the highest reduction percentage was observed in the $4 \%$ alkali treated substrate with $P$. mirabilis, which is in line with the result of hydrogen production. The COD removal efficiency of an organism is a characteristic feature determining its hydrogen production capability (Ramprakash and Muthukumar
2014). The general range of COD removal efficiencies in fermentative hydrogen production processes is between 20 and $40 \%$ (O-Thong et al. 2008). However, higher efficiencies have been exhibited with various other studies; COD removal of $71.8 \%$ was obtained during the fermentation of enzymatic hydrolysed rice mill wastewater (Ramprakash and Muthukumar 2014). About 75\% efficiency was recorded for the fermentation of paper and pulp industry effluent with Enterobacter aerogenes (Lakshmidevi and Muthukumar 2010). In the fermentation of palm oil mill effluent, a COD removal efficiency of $63 \%$ was obtained which could enhance hydrogen production (O-Thong et al. 2008).

The results of the present study are compared with previous reports of biohydrogen production with different substrates by dark fermentation (Table 4).

\section{Conclusion}

The study succeeded in producing hydrogen gas from pretreated aquatic weed E.crassipes through anaerobic fermentation. Out of the twelve bacteria isolated from different sources of wastewater, ten strains had the potential of producing hydrogen under anaerobic condition. These bacterial species belonged to five genera, namely Salmonella, Pseudomonas, Proteus, Klebsiella and Providencia. Of them, Pseudomonas sp. and Proteus sp. produced higher amount of hydrogen and hence were selected for the anaerobic experiments with acid and alkali pre-treated $E$. 
crassipes. These two bacteria were sequenced through PCR technique to identify the species as $P$. aeruginosa and $P$. mirabilis. The results of the experimental analysis show that alkali treated substrate produced higher amount of hydrogen than that of acid treated substrates. Comparing the efficiency of the bacteria, $P$. aeruginosa was found to produce higher percentage of hydrogen.

Acknowledgements The authors are thankful to Kerala State Council for Science Technology and Environment (KSCSTE), Govt. of Kerala, India (JM), and Directorate of Environment and Climate Change, Govt. of Kerala, India (DMT), for research fellowship and also to Ms. Deepa Nair (NCESS) for the assistance provided in the analysis part. The authors are also thankful to Prof. (Dr.) A.P. Thomas, Director, ACESSD, M.G. University, Kerala, for the valuable suggestions for the improvement of the manuscript.

\section{Compliance with ethical standards}

Conflict of interest The authors have no conflict of interest in the present work.

\section{References}

Aguilar R, Ramirez JA, Garrote G, Vazquez M (2002) Kinetic study of the acid hydrolysis of sugarcane bagasse. J Food Eng 55:309-318

Alkaya E, Demirer GN (2011) Anaerobic acidification of sugar-beet processing wastes: effect of operational parameters. Biomass Bioenergy 35(1):32-39

Antonopoulou G, Lyberatos G (2011) Chemical pre-treatment of sweet sorghum biomass for hydrogen production. In: Proceedings of the 12th international conference on environmental science and technology rhodes, Greece, p A-86

APHA (1998) Standard methods for the examination of water and wastewater, 19th edn. American Public Health Association, Washington

Argun H, Dao S (2016) Bio-hydrogen production from waste peach pulp by dark fermentation: effect of inoculum addition. Int $\mathrm{J}$ Hydrog Energy 42(4):2569-2574

Argun H, Kargi F, Kapdan IK (2009) Microbial culture selection for bio-hydrogen production from waste ground wheat by dark fermentation. Int J Hydrog Energy 34:2195-2200

Aswathy US, Sukumaran RK, Devi GL et al (2009) Bio-ethanol from water hyacinth biomass: an evaluation of enzymatic saccharification strategy. Bioresour Technol 101:925-930

Balat M (2008) Potential importance of hydrogen as a future solution to environmental and transportation problems. Int $\mathrm{J}$ Hydrog Energy 33(15):4013-4029

Barrow GI, Feltham RKA (1974) Cowan and steel's manual for the identification of medical bacteria, 3rd edn. Cambridge University Press, Cambridge

Barua VB, Kalamdhad AS (2016) Water hyacinth to biogas: a review. Pollut Res 35(3):491-501

Benemann JR (1996) Hydrogen biotechnology: progress and prospects. Nat Biotechnol 14:1101-1103

Bergier I, Salis SM, Miranda CHB, Ortega E, Luengo CA (2012) Biofuel production from water hyacinth in the Pantanal wetland. Ecohydrol Hydrobiol 12:77-84

Brown JB, Brutoco R, Cusumano JA (2007) Hydrogen revolution: growth, jobs, security \& sustainability. Freedom from mid-east oil, 1st edn. World Business Academy, Santa Barbara, pp 403-438

Cai M, Liu J, We Y (2004) Enhanced biohydrogen production from sewage sludge with alkaline pre-treatment. Environ Sci Technol 38:3195-3202

Center TD, Dray GA Jr, Jubindsky GP, Drodowitz MJ (1999) Biological control of water hyacinth under conditions of maintenance management: can herbicides and insects be integrated? Environ man 23:241-256

Cheng J, Xie B, Zhou J, Song W, Cen K (2010) Cogeneration of $\mathrm{H}_{2}$ and $\mathrm{CH}_{4}$ from water hyacinth by two-step anaerobic fermentation. Int J Hydrog Energy 35(7):3029-3035

Chuang YS, Lay CH, Sen B, Chen CC, Gopalakrishnan K, Wud JH, Lin CS, Lin CY (2011) Biohydrogen and biomethane from water hyacinth (Eichhornia crassipes) fermentation: effects of substrate concentration and incubation temperature. Int J Hydrog Energy 36(21):14195-14203

Costa JB, Rossi DM, De Souza EA et al (2011) The optimization of biohydrogen production by bacteria using residual glycerol from biodiesel synthesis. J Environ Sci Health ATox Hazard Subst Environ Eng 46(13):1461-1468

Cui M, Yuan Z, Zhi X, Shen J (2009) Optimization of biohydrogen production from beer lees using anaerobic mixed bacteria. Int $\mathrm{J}$ Hydrog Energy 34:7971-7978

Das D, Veziroglu TN (2001) Hydrogen production by biological processes: a survey of literature. Int $\mathrm{J}$ Hydrog Energy 26(1):13-28

Das D, Veziroglu TN (2008) Advances in biological hydrogen production processes. Int J Hydrog Energy 33:6046-6057

Das A, Ghosh P, Paul T, Ghosh U, Pati BR, Mondal KC (2016) Production of bioethanol as useful biofuel through the bioconversion of water hyacinth (Eichhornia crassipes). Biotech 6(1):70

Dhar BR, Elbeshbishy E, Hafez H, Lee HS (2015) Hydrogen production from sugar beet juice using an integrated biohydrogen process of dark fermentation and microbial electrolysis cell. Bioresour Technol 198:223-230

DuBois M, Gilles K, Hamilton J, Rebers P, Smith F (1956) Colorimetric method for determination of sugars and related substances. Anal Chem 28(3):350-356

Elsharnouby O, Hafez H, Nakhla G et al (2013) A critical literature review on biohydrogen production by pure cultures. Int J Hydrog Energy 38:4945-4966

Ewan B, Allen R (2005) A figure of merit assessment of the routes to hydrogen. Int J Hydrog Energy 30:809-819

Fang HHP, Liu H (2002) Effect of $\mathrm{pH}$ on hydrogen production from glucose by a mixed culture. Bioresour Technol 82:87-93

Fangkum A, Reungsang A (2011) Biohydrogen production from sugarcane bagasse hydrolysate by elephant dung: effects of initial $\mathrm{pH}$ and substrate concentration. Int $\mathbf{J}$ Hydrog Energy 36(14):8687-8696

Gunnarsson CC, Petersen CM (2007) Water hyacinths as a resource in agriculture and energy production: a literature review. Waste Manage 27:117-129

Guo WQ, Ren NQ, Wang XJ, Xiang WS, Meng ZH, Ding $J$ et al (2008) Biohydrogen production from ethanol-type fermentation of molasses in an expanded granular sludge bed (EGSB) reactor. Int J Hydrog Energy 33:4981-4988

Guo XM, Trably E, Latrille E et al (2010) Hydrogen production from agricultural waste by dark fermentation: a review. Int J Hydrog Energy 35(19):10660-10673

Hay JXW, Wu TY, Juan JC, Jahim J (2013) Biohydrogen production through photo fermentation or dark fermentation using waste as a substrate: overview, economics, and future prospects of hydrogen usage. Biofuels Bioprod Biorefining 7:334-352 
Ibrahim MM, El-Zawawy WK, Abdel-Fattah YR et al (2011) Comparison of alkaline pulping with steam explosion for glucose production from rice straw. Carbohydr Polym 83(2):720-726

Idrees M, Adnan A, Sheikh S, Qureshi FA (2013) Optimization of dilute acid pretreatment of water hyacinth biomass for enzymatic hydrolysis and ethanol production. EXCLI J 12:30-40

Kapdan IK, Kargi F (2006) Bio-hydrogen production from waste materials. Enzym Microb Technol 38:569-582

Kargi F, Eren NS, Ozmihci S (2012) Hydrogen gas production from cheese whey powder (CWP) solution by thermophilic dark fermentation. Int J Hydrog Energy 37:2260-2266

Kumar A, Singh LK, Ghosh S (2009) Bioconversion of lignocellulosic fraction of water-hyacinth (Eichhornia crassipes) hemicellulose acid hydrolysate to ethanol by Pichia stipitis. Bioresour Technol 100:3293-3297

Kumar G, Sivagurunathan P, Lin CY (2013) Hydrogen fermentation potential of $E$. coli XL1 blue using various carbon sources. J Environ Appl Biores 1(2):19-23

Lakshmidevi R, Muthukumar K (2010) Enzymatic saccharification and fermentation of paper and pulp industry effluent for biohydrogen production. Int J Hydrog Energy 35(8):3389-3400

Lay CH, Sen B, Chen CC, Wu JH, Lee SC, Lin CY (2013) Cofermentation of water hyacinth and beverage wastewater in powder and pellet form for hydrogen production. Bioresour Technol 135:610-615

Lazaro CZ, Perna V, Etchebehere C, Varesche MBA (2014) Sugarcane vinasse as substrate for fermentative hydrogen production: the effects of temperature and substrate concentration. Int J Hydrog Energy 39:6407-6418

Levin DB, Sparling R, Islam R, Cicek N (2006) Hydrogen production by Clostridium thermocellum 27405 from cellulosic biomass substrates. Int J of Hydrog Energy 31(11):1496-1503

Li C, Fang HHP (2007) Fermentation hydrogen production from wastewater and solid wastes by mixed cultures. Crit Rev Environ Sci Technol 37:1-39

Lin $\mathrm{CY}$, Hung $\mathrm{CH}$, Chen $\mathrm{CH}$ et al (2006) Effects of initial pH on fermentative hydrogen production from xylose using natural mixed cultures. Process Biochem 41:1383-1390

Liu CM, Chu CY, Lee WY, Li YC, Wu SY, Chou YP (2013) Biohydrogen production evaluation from rice straw hydrolysate by concentrated acid pre-treatment in both batch and continuous systems. Int J Hydrog Energy 38:15823-15829

Luque GM, Bellard C, Bertelsmeier C, Bonnaud E, Genovesi P, Simberloff D, Courchamp F (2013) Alien species: monster fern makes IUCN invader list. Nature 498(7452):37

Ma F, Yang N, Xu C, Yu H, Wu J, Zhang X (2010) Combination of biological pretreatment with mild acid pretreatment for enzymatic hydrolysis and ethanol production from water hyacinth. Bioresour Technol 101(24):9600-9604

Marc A, Koohi-Fayegh RS (2016) The prospects for hydrogen as an energy carrier: an overview of hydrogen energy and hydrogen energy systems. Energy Ecol Environ 1(1):10-29

Marone A, Izzo G, Mentuccia L, Massini G, Paganin P, Rosa S et al (2014) Vegetable waste as substrate and source of suitable microflora for bio-hydrogen production. Renew Energy 68:6-13

Mathur SM, Singh P (2004) Development and performance evaluation of a water hyacinth chopper cum crusher. Biosyst Eng 88(4):411-418

Minnan L, Jinli H, Xiaobin W, Huijuan X, Jinzao C, Chuannan L et al (2005) Isolation and characterization of a high $\mathrm{H}_{2}$-producing strain Klebsiella oxytoca HP1 from a hot spring. Res Microbiol 156:76-81

Mishima D, Kuniki M, Sei K, Soda S, Ike M, Fujita M (2008) Ethanol production from candidate energy crops: water hyacinth
(Eichhornia crassipes) and water lettuce (Pistia stratiotes L.). Bioresour Technol 99:2495-2500

Mohanty P, Pant KK, Mittal R (2015) Hydrogen generation from biomass materials: challenges and opportunities. Wiley Interdiscip Rev Energy Environ 4:139-155

Momirlan M, Veziroglu TN (2002) Current status of hydrogen energy. Renew Sustain Energy Rev 6:141-179

Nasra N, Guptab M, Elbeshbishyc E et al (2014) Biohydrogen production from pretreated corn cobs. Int $\mathrm{J}$ Hydrog Energy 39(35):19921-19927

Nath K, Das D (2003) Hydrogen from biomass. Curr Sci 85(3):265-271

Nath K, Das D (2004) Biohydrogen production as a potential energy source - Present state of art. JSIR 63:729-738

Oncel S, Sukan FV (2011) Effect of light intensity and the light: dark cycles on the long term hydrogen production of Chlamydomonas reinhardtii by batch cultures. Biomass Bioenergy 35(3):1066-1074

O'Sullivan C, Rounsefell B, Grinham A, William C, Udy J (2010) Anaerobic digestion harvested aquatic weeds: water hyacinth (Eichhornia crassipes), cabomba (Cabomba Caroliniana) and savinia (Salvinia molesta). Ecol Eng 36:1459-1468

O-Thong S, Prasertsan P, Intrasungkha N et al (2008) Optimization of simultaneous thermophilic fermentative hydrogen production and COD reduction from palm oil mill effluent by Thermoanaerobacterium-rich sludge. Int J Hydrog Energy 33(4):1221-1231

Parolin P, Rudolph B, Bartel S, Bresch C, Poncet C (2012) World wide invasion pathways of the South American Eichhornia crassipes. Acta Hortic 937:1133-1140

Patel S (2012) Threats, management and envisaged utilizations of aquatic weed Eichhornia crassipes: an overview. Rev Environ Sci Biotechnol 11:249-259

Patel SKS, Purohit H, Kalia VC (2010) Dark fermentative hydrogen production by defined mixed microbial cultures immobilized on ligno-cellulosic waste materials. Int $J$ Hydrog Energy 35:10674-10681

Pattra S, Sittijunda S (2017) Biohydrogen productions from hydrolysate of water hyacinth stem (Eichhornia crassipes) using anaerobic mixed cultures. Sains Malays 46(1):51-58

Prakasaham RS, Satish T, Brahmaiah P et al (2009) Biohydrogen production from renewable agri-waste blend: optimization using mixer design. Int J Hydrog Energy 34(15):6143-6148

Pudukudy M, Yaakob Z, Mohammad M, Narayanan B, Sopian K (2014) Renewable hydrogen economy in Asia-opportunities and challenges: an overview. Renew Sustain Energy Rev 30:743-757

Ramos LP (2003) The chemistry involved in the steam treatment of lignocellulosic materials. Quim Nova 26:863-871

Ramprakash B, Muthukumar K (2014) Comparative study on the production of biohydrogen from rice mill wastewater. Int $\mathrm{J}$ Hydrog Energy 39(27):14613-14621

Ray P, Kumar S, Pandey S (2009) Impact evaluation of Neo-chetina spp. on different growth stages of water hyacinth. J. Plant Prot Res 49(1):7-14

Reginatto V, Antônio RV (2015) Fermentative hydrogen production from agro-industrial lignocellulosic substrates. Braz J Microbiol 46(2):323-335

Ren N, Wang A, Cao G, Xu J, Gao L (2009) Bioconversion of lignocellulosic biomass to hydrogen: potential and challenges. Biotechnol Adv 27:1051-1060

Reungsang A, Sreela-or C (2013) Bio-hydrogen production from pineapple waste extract by anaerobic mixed cultures. Energies 6:2175-2190

Sathyanagalakshmi Sindhu R, Binod P, Usha K, Janu RK, Sukumaran, Pandey A (2011) Bioethanol production from acid pretreated water hyacinth by separate hydrolysis and fermentation. J Sci Ind Res 70:156-161 
Seol E, Kim S, Raj SM et al (2008) Comparison of hydrogenproduction capability of four different Enterobacteriaceae strains under growing and non-growing conditions. Int J Hydrog Energy 33:5169-5175

Shanab SMM, Hanafy EA, Shalaby EA (2017) Water hyacinth as non-edible source for biofuel production. Waste Biomass Valoris. doi:10.1007/s12649-016-9816-6

Sharma A, Aggarwal NK, Saini A, Yadav A (2016) Beyond biocontrol: water hyacinth-opportunities and challenges. J Environ Sci Technol 9:26-48

Show KY, Lee DY, Tay JH, Lin CY, Chang JS (2012) Biohydrogen production: current perspectives and the way forward. Int $\mathrm{J}$ Hydrog Energy 37(20):15616-15631

Sills DL, Gossett JM (2011) Assessment of commercial hemicellulases for saccharification of alkaline pretreated perennial biomass. Bioresour Technol 102(2):1389-1398

Singhal Y, Singh R (2014) Effect of microwave pre-treatment of mixed culture on biohydrogen production from waste of sweet produced from Benincasa hispida. Int $\mathbf{J}$ of Hydrog Energy 39:7534-7540

Sivaramakrishna D, Sreekanth D, Sivaramakrishnan M et al (2014) Effect of system optimizing conditions on biohydrogen production from herbal wastewater by slaughterhouse sludge. Int $\mathbf{J}$ of Hydrog Energy 39:7526-7533

Soniagandhi S, Krishnaveni M (2013) Bio-hydrogen production by Pseudomonas stutzeri KF532951. Int J of Chem and Anal Sci 4(4):210-212

Stubbs TL, Kennedy AC (2012) Microbial weed control and microbial herbicides. In: Alvarez-Fernandez R (ed) Herbicides-environmental impact studies and management approaches. In Tech, Rijeka, pp 135-166

Su H, Cheng J, Zhou J, Song W, Cen K (2010) Hydrogen production from water hyacinth through dark- and photo-fermentation. Int J Hydrog Energy 35:8929-8937

Suleman F, Dincer I, Agelin-Chaab M (2015) Environmental impact assessment and comparison of some hydrogen production options. Int J Hydrog Energy 40(21):6976-6987

Sun Y, Cheng J (2002) Hydrolysis of lignocellulosic materials for ethanol production: a review. Bioresour Technol 83:1-11
Sylas VP (2010) An ecological study of the macrophytic vegetation of the Kuttanad wetland ecosystem. PhD Thesis, Mahatma Gandhi University, Kottayam, p 310

Teater C, Yue Z, MacLellan J, Liu Y, Liao W (2011) Assessing solid digestate from anaerobic digestion as feedstock for ethanol production. Bioresour Technol 102:1856-1862

Thomas DM, Mechery J, Paulose SV (2016) Carbon dioxide capture strategies from flue gas using microalgae: a review. Environ Sci Pollut Res 23:16926-16940

Thomsen AB, Thygesen A, Bohn V et al (2006) Effects of chemicalphysical pre-treatment processes on hemp fibres for reinforcement of composites and for textiles. Ind Crops Prod 24:113-118

Vijayaraghavan K, Ahmad D, Ibrahim MKB (2006) Biohydrogen generation from jackfruit peel using anaerobic contact filter. Int $\mathbf{J}$ Hydrog Energy 31:569-579

Vivekanand V, Olsen EF, Eijsink VG, Horn SJ (2013) Effect of different steam explosion conditions on methane potential and enzymatic saccharification of birch. Bioresour Technol 127:343-349

Wang J, Wan W (2009) Factors influencing fermentative hydrogen production: a review. Int J Hydrog Energy 34:799-811

Wang S, Ma Z, Zhang T, Bao M, Su H (2017) Optimization and modeling of biohydrogen production by mixed bacterial cultures from raw cassava starch. Front Chem Sci Eng 11(1):100-106

Watanapokasin RY, Boonyakamol A, Sukseree S et al (2009) Hydrogen production and Anaerobic decolorization of wastewater containing Reactive Blue 4 by a bacterial consortium of Salmonella subterranean and Paenibacilluspolymyxa. Biodegradation 20:411-418

Xie B, Guo L, Li XM et al (2008) Bio-hydrogen production from different pretreated sludge by Pseudomonas sp. GL1 and changes in the liquid phases. Huan Jing Ke Xue 29(4):996-1001

Yan J, Wei Z, Wang Q, He M, Li S, Irbis C (2015) Bioethanol production from sodium hydroxide/hydrogen peroxide pretreated water hyacinth via simultaneous saccharification and fermentation with a newly isolated thermotolerant Kluyveromyces marxianu strain. Bioresour Technol 193:103-109

Zhu Y, Ren X, Wu C (2004) Influence of alkali treatment on the structure of new cell fibers. J Appl Polym Sci 93(4):1731-1735 